\title{
Peanut cake concentrations in massai grass silage
}

\section{La harina de cacahuete en el ensilaje de hierba Massai}

\author{
Luciano S. Lima, ${ }^{1}$ M.Sc, Ronaldo L. Oliveira, ${ }^{1}$ Ph.D, Máikal S. Borja, ${ }^{1 *}$ M.Sc, \\ Adriana R. Bagaldo, ${ }^{2}$ Ph.D, Edgar FS. Faria, ${ }^{1}$ M.Sc, Thadeu M. Silva, ${ }^{1}$ M.Sc, \\ Gleidson GP. Carvalho, ${ }^{1}$ Ph.D, Cláudio VDM. Ribeiro, ${ }^{1}$ Ph.D.
}

\begin{abstract}
${ }^{1}$ Universidade Federal da Bahia, Escola de Medicina Veterinária e Zootecnia, Departamento de Produção Animal, Salvador, Brasil, Areia, Brasil. '2Universidade Federal do Recôcavo da Bahia, Pós Graduação em Ciência Animal, Cruz da Almas, Brasil. *Correspondence: maikalborja@hotmail.com.
\end{abstract}

Recibido: Octubre de 2011; Aceptado: Agosto de 2012.

\begin{abstract}
Objective. This experiment was conducted to evaluate the best concentration of peanut cake in the ensiling of massai grass of the chemical-bromatological composition, fermentative characteristics, forage value rate, ingestion estimates, and digestibility of dry matter in the silage. Materials and methods. The experiment was carried out at the Experimental Farm of São Gonçalo dos Campos at the Federal University of Bahia, Brazil. The treatments consisted of massai grass that was cut at 40 days and dehydrated, in addition to $0 \%, 8 \%, 16 \%$, and $24 \%$ peanut cake in the fresh matter and treatment without cake. The material was compressed in experimental silos ( 7 liter) that were opened after 76 days. Results. The addition of $8-24 \%$ peanut cake improved the silage's chemical-bromatological parameters, increased the dry matter and non-fiber carbohydrates and reduced the fibrous components. There was a linear increase in the estimated values of digestibility and the ingestion of dry matter depending on the levels of peanut cake in the silage. There was an improvement in the fermentative characteristics, with a quadratic effect positive for levels of ammoniacal nitrogen. The forage value rate increased linearly with the inclusion of peanut cake. Conclusions. The inclusion of up to $24 \%$ peanut cake during ensiling of massai grass increases the nutritive value of silage and improves fermentation characteristics.
\end{abstract}

Key words: Biofuels, nutrition, ruminants, silage, supplements (Source: $C A B$ ). 


\section{RESUMEN}

Objetivo. Este experimento se realizó para evaluar el mejor nivel de inclusión de harina de cacahuete en el ensilado de hierba massai a través de la composición química-bromatológica, las características fermentativas, la tasa de valor forrajero, las estimaciones de la ingestión y la digestibilidad de la materia seca. Materiales y métodos. El experimento se llevó a cabo en la Granja Experimental de São Gonçalo dos Campos, en la Universidad Federal de Bahía. Los tratamientos fueron hierba massai cortada a 40 días, deshidratada, además de un $8 \%, 16 \%$ y $24 \%$ de harina de maní en la materia fresca, además de tratamiento sin harina de cacahuete. El material se comprimió en silos experimentales que se abrieron después de 76 días. Resultados. La adición de harina de cacahuete $24 \%$ mejor que el ensilaje de productos químicos bromatológicos parámetros, el aumento de la materia seca y carbohidratos sin fibra, y la reducción de los componentes fibrosos. Hubo un aumento lineal de los valores estimados de la digestibilidad y la ingestión de materia seca en función de los niveles de harina de cacahuete en el ensilaje. Se observó una mejoría en las características fermentativas, con un efecto de segundo grado para los niveles de nitrógeno amoniacal. La tasa de valor forrajero aumentó linealmente con la inclusión de harina de cacahuete. Conclusiones. La inclusión de hasta un $24 \%$ de harina de cacahuete durante el ensilaje de pasto massai aumenta el valor nutritivo del ensilaje y mejora las características de la fermentación.

Palabras clave: Biocombustibles, ensilaje, nutrición, rumiantes, suplementación (Fuente: CAB).

\section{INTRODUCTION}

Brazil has emerged as an important global producer of meat and milk. Pasture-raised animals require quality feed throughout the year so that the dairy and meat industries can remain productive.

The low availability of fodder during annual months of drought causes seasonal livestock production to be divided into wet and dry seasons. The dry season causes economic losses for producers because in most cases, the revenue from the dry season is lower than that obtained in the wet season Neiva and Vasconcelos (1).

Low cattle production in the tropics can be attributed, among other factors, to inadequate nutrition resulting from the seasonality of forage production. In an ongoing livestock production program, it is essential to eliminate this unproductive phase and provide conditions in which the animals can develop normally throughout the year with Reis et al (2).

Among the various options to fulfill the animals' nutritional requirements during periods of low forage production, roughage supplementation through silage is an excellent method for keeping the nutrient supply in balance with the requirements of the livestock. Thus, the surplus fodder from the rainy season can be stored as silage, which is a very important strategy for animal nutrition.

To obtain silage from tropical perennial forage grasses of good nutritional quality, the grasses should be harvested at young stages of maturity (60 to 70 days or less). At this stage of development, the excess moisture $(80 \%$ or more) in forage increases the risk of the proliferation of undesirable microorganisms, Jobim et al (3). The lower osmotic pressure during this stage may encourage the growth of bacteria of the genus Clostridium and bacteria, which convert sugars, lactic acid, proteins, and amino acids into acetic and butyric acids, ammoniacal nitrogen (NH3-N) and amines, substances that affect silage consumption.

In addition to the increased moisture, the tropical grasses also have a low concentration of soluble carbohydrates, which can bring about a rapid decrease in $\mathrm{pH}$ and the production of good nutritional quality silage. The soluble portion of forage grasses during ensiling is essential for the fermentation process to develop efficiently Ávila et al (4).

Alternatives of additives in the ensiling of tropical grass, have been utilized to increase the dry matter content of silage Carvalho et al (5); Carvalho et al (6) and to provide nonfiber carbohydrates, Andrade and Melotti (7); Ferreira et al (8). A good additive for ensiling tropical grasses should have high dry matter content, capacity for water absorption, high nutritional value, good flavor, high content of soluble carbohydrates, easy manipulation, Neiva and Vasconcelos (1).

The transesterification process is currently the most widely used method for biodiesel 
production. It consists of a chemical reaction between vegetable oils or animal fats and rubbing alcohol (ethanol) or methanol, encouraged by a catalyst, which also produces glycerin, a product with various applications in the chemical industry Lima et al (9). In addition to glycerin, the biodiesel production chain generates a number of other by-products such as meal and bran, both of which have a high concentration of nutrients that can be used in animal feed.

Due to their nutritional characteristics, the meal and bran that are generated during the production of biodiesel have the potential to be used as additives in the ensiling of tropical grasses. The peanut cake obtained after oil extraction is a by-product of high commercial value, as it has appropriate nutritional characteristics (Nunes et al (10); Correia et al (11); Ribeiro et al (12); Agy et al (13). Peanut cake obtained without shells contains approximately $45 \%$ protein, averaging $8.5 \% \mathrm{EE}$, at most $9.5 \%$ cellulose and approximately $83.5 \%$ TDN Santos et al (14); Suarez et al (15).

The objective of this work was to determine the best percentage of cake inclusion, derived from the production of biodiesel, in massai grass silage based on chemical-bromatological composition, fermentation characteristics, estimates of consumption and dry matter digestibility, and an forage index value.

\section{MATERIAL AND METHODS}

Field management and sampling. Experiments were conducted at the experimental Farm at the Federal University of Bahia, located in the municipality of São Gonçalo dos Campos - BA (12 $25^{\prime} 58^{\prime \prime}$ South, $38^{\circ} 58^{\prime} 01^{\prime \prime}$ West), at a distance of $108 \mathrm{~km}$ from Salvador, located in the middle region of north-central Bahia and the microregion of Feira de Santana-BA. After 40 days of regrowth, massai grass was manually cut to $10 \mathrm{~cm}$ above the soil and ground into fragments approximately $5 \mathrm{~cm}$ long, using a stationary defragmenter. The treatments were a inclusion of massai grass and various levels of peanut cake that, after being homogenized, were ensiled in 15-L plastic buckets with four repetitions per treatment.

A total of $0.0,8.0,16.0$, and $24.0 \%$ peanut cake was used in the silage, based on natural matter, which corresponds to $21.28,27.10,44.87$, and $57.44 \%$, respectively, of a DM of massai grass. The material was compacted manually with the aid of wooden bars and was sealed with tape and plastic canvas to prevent the entry of air. It was then stored at room temperature and protected from rain and sunlight. After 76 days, the experimental silos were opened and sampled from the center of each bucket.

Chemical analyses. The samples were dried in an oven at $55^{\circ} \mathrm{C}$ for $72 \mathrm{~h}$ and then ground into a 1-mm sieve for bromatological analysis of dry matter (DM), crude protein (CP), mineral matter (MM), neutral detergent fiber (NDF), acid detergent fiber (ADF), ether extract (EE), nonfiber carbohydrates (NFC), hemicellulose (HEM), cellulose (CEL), and lignin (LIG), using the methods described by Silva and Queiroz (16). An analysis of the ingredients before ensiling is shown in table 1 . Measurements of ammonia nitrogen levels (NH3-N) were performed as described by Playne and McDonald (17), and $\mathrm{pH}$ analysis was carried out using a digital potentiometer at the moment the buckets were opened.

Table 1. Chemical composition of massai grass and peanut meal used in the production of silage.

\begin{tabular}{lcc}
\hline \multicolumn{1}{c}{ Items } & $\begin{array}{c}\text { Massai } \\
\text { grass }\end{array}$ & $\begin{array}{c}\text { Peanut } \\
\text { meal }\end{array}$ \\
\hline Dry Matter (\%) $^{\text {Crude Protein }}{ }^{1}$ & 21.3 & 90.9 \\
Ether Extract $^{1}$ & 6.40 & 45.7 \\
Neutral Detergent Fiber $^{1}$ & 0.68 & 8.66 \\
Acid Detergent Fiber $^{1}$ & 67.7 & 15.4 \\
Lignin $^{1}$ & 48.6 & 11.8 \\
Cellulose $^{1}$ & 10.4 & 2.00 \\
Hemicellulose $^{1}$ & 38.2 & 9.82 \\
Non Fiber Carbohydrates $^{1}$ & 19.1 & 3.55 \\
Detergent Insoluble in Neutral Nitrogen $^{2}$ & 15.9 & 26.2 \\
Detergent Insoluble in Acid Nitrogen $^{2}$ & 30.0 & 12.2 \\
Cinzas $^{1}$ & 5.00 & 3.50 \\
\hline
\end{tabular}

$1 \%$ of dry matter, $2 \%$ of total nitrogen

Measurement the forage value index. The forage value index (FVI) was obtained through the following equations described by Teixeira and Andrade (18):

DMI $(\%$ of live weight $)=120 / \%$ NDF of DM (equation 1);

$\operatorname{DDM}(\%)=88.9-0.779 \times \mathrm{ADF} \% \mathrm{DM}$ (equation 2)；

$\mathrm{FVI}=(\mathrm{DMI} \times \mathrm{DDM}) / 1.29$ (equation 3);

DMI is dry matter intake, NDF is neutral detergent fiber, DDM is digestible dry matter, DM is dry matter, ADF is acid detergent fiber, and FVI is forage value index. 
Statistical analysis. The experimental design was completely randomized, with four treatments and four replicates per treatment. The data were analyzed using the SPSS ${ }^{\circledR} 12.0$ for variance analysis and regression, assuming a significance level of $5 \%$.

\section{RESULTS}

The peanut cake showed potential for moisture absorption because the increasing levels that were added to the ensiling massai grass provided a linear increase $(p<0.05)$ in the silages for DM, thus showing maximum values of $40.4 \%$ with the addition of $24 \%$ peanut cake. There was a linear increase in the CP content of the silage with the addition of peanut cake. Each $1 \%$ inclusion of cake in the silage corresponded to an increase of 0.68 percentage units of CP. The inclusion of levels of peanut cake reduced the levels of MM. The percentage of $E E$ increased with the addition of peanut cake to the silage, thus promoting a linear effect $(p<0.05)$. The NFC content increased with the addition of peanut cake to the silage $(p<0.05)$ at a rate of 0.23 percentage points per $1 \%$ addition. The inclusion of peanut cake in the silage promoted a reduction in the NDF and ADF in the silage $(p<0.05)$. For each $1 \%$ addition of cake, there was a reduction of 0.87 and 0.57 percentage points in NDF and ADF, respectively. The fractions of HEM, CEL and LIG decreased with the inclusion of peanut cake, demonstrating that the inclusion of this additive could make grass more digestible for livestock. The treatments did not influence the $\mathrm{pH}$ levels of the silage (Table 2).
There was an $18 \%$ reduction $(\mathrm{p}<0.05)$ of $\mathrm{NH}_{3}-\mathrm{N}$ in the silage with the inclusion of peanut cake, and the lowest level of $\mathrm{NH}_{3}-\mathrm{N}$ was estimated at 8.1\% (Figure 1).

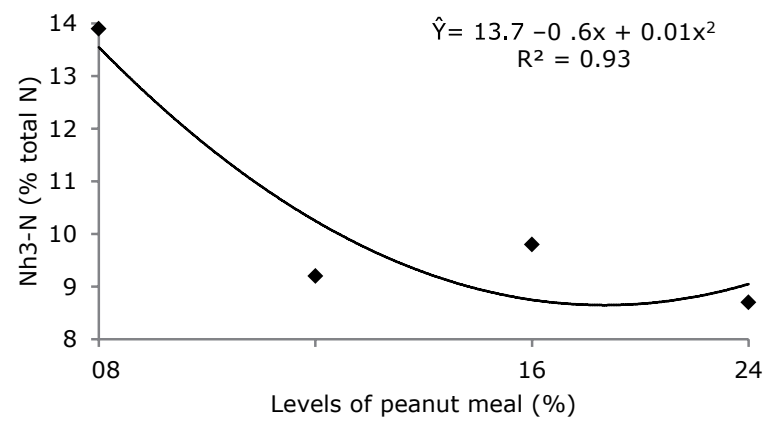

Figure 1. $\mathrm{NH}_{3}-\mathrm{N}$ of massai grass silage with added peanut cake.

In this work, the estimated intake of DM increased linearly with the inclusion of peanut cake. The massai grass silage without added peanut cake had higher levels of ADF and lignin, with corresponding lower estimates of dry matter digestibility (Table 3).

Table 3. Estimates of dry matter intake (DMI), dry matter (DM) and forage value index (FVI) of massai grass silage with levels of peanut cake.

\begin{tabular}{|c|c|c|c|c|c|c|}
\hline \multirow[t]{2}{*}{ Items } & \multicolumn{4}{|c|}{ With Peanut cake (\%) } & \multirow[t]{2}{*}{$\begin{array}{c}\text { Regression } \\
\text { Equation }\end{array}$} & \multirow[t]{2}{*}{$\mathbf{R}^{2}$} \\
\hline & 0 & 8 & 16 & 24 & & \\
\hline DMI (\% LW) 1 & 1.74 & 2.07 & 2.24 & 2.56 & $\hat{Y}=1.76+0.03 x$ & 0.98 \\
\hline DM (\%) & 51.8 & 56.9 & 59.2 & 62.2 & $\hat{Y}=52.51+0.42 x$ & 0.96 \\
\hline FVI & 70.0 & 91.7 & 103 & 124 & $\hat{Y}=71.20+2.17 x$ & 0.98 \\
\hline
\end{tabular}

$1 \%$ Live weight

Table 2. The treatments the $\mathrm{pH}$ levels of the silage.

\begin{tabular}{|c|c|c|c|c|c|c|c|}
\hline \multirow{2}{*}{ Constituents } & \multicolumn{4}{|c|}{ Included Peanut meal (\%) } & \multirow{2}{*}{ Regression Equation } & \multirow{2}{*}{$\mathbf{R}^{2}$} & \multirow{2}{*}{ CV } \\
\hline & 0 & 8 & 16 & 24 & & & \\
\hline Concentrations of dry matter $(\%)$ & 22.3 & 29.8 & 35.1 & 40.4 & $\hat{Y}=23+0.74 x$ & 0.99 & 4.09 \\
\hline Crude protein $^{1}$ & 6.29 & 13.0 & 17.0 & 23.2 & $\hat{Y}=6.7+0.68 x$ & 0.99 & 8.32 \\
\hline Mineral matter ${ }^{1}$ & 12.6 & 9.57 & 7.36 & 7.35 & $\hat{Y}=11.9-0.21 \mathrm{X}$ & 0.85 & 5.08 \\
\hline Ether extract ${ }^{1}$ & 1.30 & 4.61 & 5.26 & 5.69 & $\hat{Y}=2.1+0.17 x$ & 0.80 & 12.5 \\
\hline Non-fiber carbohydrates ${ }^{1}$ & 11.0 & 15.0 & 16.6 & 16.6 & $\hat{Y}=12+0.23 x$ & 0.81 & 12.6 \\
\hline Neutral detergent fiber ${ }^{1}$ & 68.8 & 57.8 & 53.5 & 43.9 & $\hat{Y}=67.2-0.87 x$ & 0.96 & 3.4 \\
\hline acid detergent fiber ${ }^{1}$ & 47.6 & 41.0 & 38.1 & 34.2 & $\hat{Y}=46.7-0.53 x$ & 0.96 & 3.65 \\
\hline Hemicellulose $^{1}$ & 21.2 & 16.8 & 15.3 & 12.6 & $\hat{Y}=20.6-0.33 x$ & 0.95 & 7.14 \\
\hline Cellulose $^{1}$ & 34.5 & 29.5 & 27.7 & 25.0 & $\hat{Y}=33.7-0.37 x$ & 0.95 & 4.23 \\
\hline Lignin ${ }^{1}$ & 13.1 & 11.5 & 10.4 & 9.2 & $\hat{Y}=12.9-0.16 x$ & 0.99 & 4.68 \\
\hline Hydrogen potential & 4.43 & 4.2 & 4.2 & 4.3 & $\hat{Y}=4.31$ & - & 4.10 \\
\hline $\mathrm{N}-\mathrm{NH}_{3} / \mathrm{N}$ total & 13.9 & 9.14 & 8.92 & 8.37 & $\hat{Y}=3.69-0.61 x+0.01 x^{2}$ & 0.94 & 15.8 \\
\hline
\end{tabular}

1 (\%DM); ammoniacal nitrogen $\left(\mathrm{NH}_{3}-\mathrm{H}\right)$ from massai grass silage with different levels of peanut meal $(\% \mathrm{MN})$ 
The FVI (Figure 2) was found to be lower for the silage without added peanut cake, which was classified as grade 3 forage based on the work by Teixeira and Andrade (18).

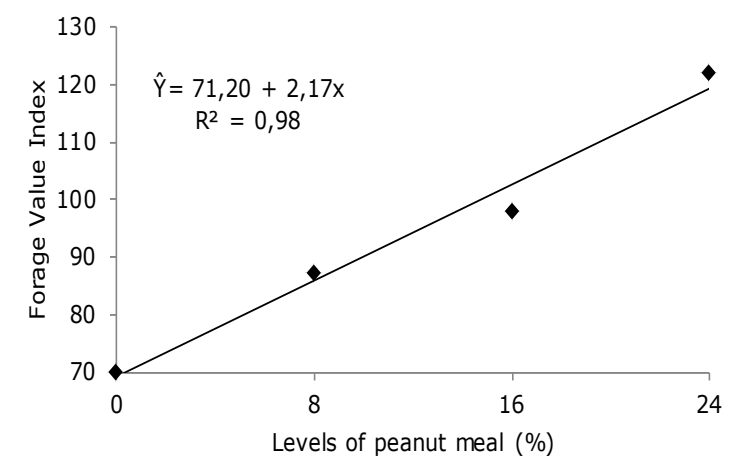

Figure 2. Forage Value Index In Massai Grass With Peanut Cake Added.

\section{DISCUSSION}

The treatments with inclusion levels of $16 \%$ peanut cake had DM contents of $30-35 \%$ above the established parameters for good quality silage according to Jobim et al (3), thus justifying the use of this cake as an efficient means to sequester moisture. The results of this study are in accordance with those obtained by Ribeiro et al (19), who also observed significant increases in the DM of tropical grass silage Tanzania grass when they used similar levels of wheat bran as an additive.

The linear increase in $\mathrm{CP}$ result was due to the higher CP content of the peanut cake $(45.70 \%)$ compared to massai grass $(6.40 \%)$. The CP content of silage exceeds the minimum levels of 6 to $8 \%$ that are needed to cause effective microbial fermentation in the rumen. Zanine et al (20) observed an increase of $51.7 \%$ in protein value when $15 \%$ wheat bran was added to the silage of elephant grass, which is in accordance with the results of this work. The results of this study are similar to studies using other additives such as cocoa bran Carvalho et al (5) and coffee shells Carvalho et al (6) that promote an increase in the protein content of silage. Thus, both the peanut cake and other additives show positive results for improving the protein content of grass silages to meet the nutritional requirements of animals, especially during periods of quality food scarcity.

The mineral matter levels in the silages in this work are justified by a lower percentage of MM in peanut cake $(4.06 \%)$ as compared to the massai grass $(9.28 \%)$. These results corroborate those found by Ribeiro et al (19) in the silage of Tanzania grass with high levels of wheat bran.

The increased levels of $\mathrm{EE}$ in the silages are justified, because cake with a high oil concentration generally varies depending on the quality of the seeds and the method used in the oil extraction. The values of EE in the silages are in agreement with reports in the literature Carvalho et al (6) at levels (5-7\% DM) that would not impair animal performance. According to Oliveira et al (21), high levels of fat in the diet of ruminants promote physical involvement of fiber and prevent microbial attack, thus reducing the in vivo digestibility of dry matter.

The higher content of NFC in the peanut cake in relation to massai grass (Table 1 ) at the time of silage explains the high levels of NFC fraction in the silage. The high concentration of CNF in the silage may also be associated with the breaking of chemical bonds in structural carbohydrates, mainly hemicellulose, within the grass Ferreira et al (8).

The levels NDF and ADF in the silage decreased with the inclusion levels of peanut cake. These results are associated with lower levels of NDF and ADF in the additive compared to massai grass at ensiling. Fontanelli et al (22) found a mean value of $60.7 \%$ of NDF in 246 maize silages from different regions of the state, while Costa et al (23) cite values ranging between 52.1 and $59.5 \%$ for corn silage. NRC (24), however, has an average content of 45\% NDF in 1033 samples of silage corn analyzed in the U.S. According to Mulligan et al (25), these differences can be attributed to the intrinsic higher content of NDF in grasses of tropical origin and, likely, to inadequate techniques silage existing in Brazil, which lead to greater loss of soluble sugars, thus increasing the level of NDF.

The reduction in the NDF of the silages may help to improve the intake and digestibility of $\mathrm{DM}$; however, NDF values greater than $55-60 \%$ in DM correlate negatively with food intake NRC (24).

The high values of ADF may restrict the quality of the silage and may limit its use for animals with special dietary needs Ribeiro et al (19).

With an increase in NFC, the corresponding decrease in lignin content will enhance digestibility. This fact can be explained by the power of recalcitrant lignin, which is mitigated by the lower concentration of the sample and allows for better use of fiber by micro-organisms Mello et al (26). Ferrari and Lavezzo (27) observed a linear reduction in hemicellulose 
when increasing levels of cassava were added to a silage of elephant grass containing $18.7 \%$ DM. Carvalho et al (6) also observed a decrease in hemicellulose in elephant grass silage containing levels the coffee.

The high $\mathrm{pH}$ in conventionally preserved silages is indicative of an increased production of acetic and butyric acid, which is characteristic of fermentation reactions Jobim et al (3).

The $\mathrm{pH}$ value of silage, taken alone, is not considered to be a good criterion for evaluating fermentation Zanine et al (28) because its antibacterial effects depend on the speed of the reduction of $\mathrm{pH}$. The addition of peanut cake did not contribute to this reduction. With the exception of silage without added peanut cake, values found in this study (Table 2 ). Were within the range considered to be optimal (between 3.8 and 4.3 ) for desirable fermentation Jobim et al (3).

When grass silage is harvested younger and has higher nutritional value, it favors the development of spoilage microorganisms, mainly clostridial bacteria. Which produce ammonia and butyric acid due to high humidity (over $70 \%$ ), high buffering capacity, and low soluble carbohydrates (less than $5 \%$, based on MS) Zanine et al (28). Ferreira et al (29) evaluated the chemical composition of silage and obtained values from 48.80 to $39.67 \%$ ADF for elephant grass silages containing dehydrated pineapple; these values are close to those found in the present study.

The efficiency of additives in improving the quality of fermentation can be explained by the supply of soluble carbohydrates, increases in DM levels, or the reduction of the buffering capacity of forage, all of which are factors that have a direct bearing on reducing the $\mathrm{pH}$ of the silage. Ávila et al (4) concluded that the addition of wheat bran improved the fermentation characteristics of silage of Tanzania grass by increasing the osmotic pressure, rather than only by having higher levels of soluble carbohydrates.

There was a reduction of $\mathrm{NH}_{3}-\mathrm{N}$ in the silage. It is noteworthy that in the highest level of inclusion of peanut cake, there was a trend of increasing $\mathrm{NH}_{3}-\mathrm{N}$. It is likely that the high amount of sugar favored the growth of microorganisms that grow in media with very low $\mathrm{pH}$ and high concentrations of residual sugar, like some species of yeast, which would instigate the deterioration of silage. Similar results were observed by Zanine et al (28) by including cane sugar, which is an additive with a high concentration of soluble carbohydrates in Tanzania grass and elephant grass silages, respectively.

Consumption of silage is usually lower than the consumption of other forages, such as hay and pasture grass. This is attributed to the presence of fermentation products, such as acetic acid, that lower the $\mathrm{pH}$ and degrade protein to ammonia Playne and McDonald (17), which can be reduced when establishing procedures that are appropriate for fermentation.

The estimated amount of digestible DM increased linearly with the inclusion of peanut cake, which is explained by the inverse relationship that this variable has with NDF. The higher the levels of $\mathrm{NDF}$, the faster the rumen is filled and the faster the animal stops ingesting forage, often ingesting a smaller amount of DM.

These results are consistent with those reported by Mullingan et al (25) when assessing silages of maize and sorghum, who commented on the high negative correlation between lignin content and FDA and this content with digestibility.

The FVI tropical forages proposed by Teixeira and Andrade (17) can be used to compare tropical forages and determine equivalent degrees of quality. This index is divided into 6 grades, from IVF> 122, which is considered superior. The IVF was found to be lower for silage without added peanut cake, which was classified as grade 3 forage based on the work by Teixeira and Andrade (17), the same grade that applies to elephant grass in nature IVF:78 and andropogon grass IVF:73, forages widely used in feed for ruminants. The highest forage value index was obtained in silage with the addition of $24 \%$ peanut cake to massai grass, which was better than the level found by Ribeiro et al (19), with the addition of $34 \%$ bran wheat to Tanzania grass, resulting in an IVF 141.61. However, both results are comparable to alfalfa as fodder in nature, because it is a forage of a higher classification than that of Teixeira and Andrade (17). The increase in IVF from the addition of peanut cake is explained by the low NDF and ADF of this additive. With the addition of the peanut cake, the levels of NDF and ADF in silage are reduced (Table 2), and these fractions have an inverse relationship to IVF.

In conclusion, the inclusion of up to $24 \%$ peanut cake to the silage of massai grass increases the nutritive value of silage. Higher rates of forage value and estimates of dry matter intake and digestibility are obtained with the addition of up to $24 \%$ peanut cake during the ensiling of massai grass. 


\section{REFERENCES}

1. Neiva JNM, Vasconcelos VR. Técnicas para produção intensiva de volumosos em regiões semi-áridas. Cienc Animal 2000; 10:70-74.

2. Reis RA, Ruggieri AC, Casagrande DR, Páscoa AG. Supplementation of beef cattle as strategy of pasture management. R Bras Zootecn 2009; 38:147-159.

3. Jobim CC, Cecato U, Canto MW. Produção e utilização da forragens conservadas. Maringá: Masson; 2008.

4. Ávila CLS, Pinto JC, Evangelista AR, Morais AR, Figueiredo HCP, Tavares VB. Perfil de fermentação das silagens de capim-tanzânia com aditivos - teores de nitrogênio amoniacal e pH. Cienc Agrotec 2003; 27:1144-115.

5. Carvalho GGP, Garcia R, Pires AJV, Pereira OG, Azevedo JAG, Carvalho BMA, Cavali J. Valor nutritivo de silagens de capimelefante emurchecido ou com adição de farelo de cacau. R Bras Zootec 2007; 36:1495-1501.

6. Carvalho GGP, Garcia R, Pires AJV, Pereira OG, Azevêdo JAG, Carvalho BMA, Cavali J. Valor nutritivo e características fermentativas de silagem de capimelefante com adição de casca de café. R Bras Zootec 2007; 36:1875-1881.

7. Andrade SJT, Melott L. Efeito de alguns tratamentos sobre a qualidade da silagem de capim-elefante cultivar Napier (Pennisetum purpureum, Schum). Braz J Vet Res Anim Sci 2004; 41:409-415.

8. Ferreira $A C H$, Neiva JNM, Rodriguez NM, Lôbo RNB, Vasconcelos VR. Valor nutritivo das silagens de capim-elefante com diferentes níveis de subprodutos. R Bras Zootec 2004; 33:1380-1385.

9. Lima JRO, Silva RB, Silva CCM, Santos LSS, Santos Júnior JR, Moura EM, Moura CVR. Biodiesel de babaçu (Orbignya sp.) obtido por via etanólica. Quim Nova 2007; 30:600-603.
10. Nunes AS, Oliveira RL, Borja MS, Bagaldo AR, Macome FM, Jesus IB, Silva TM, Barbosa LP, Garcez Neto AF. Consumo, digestibilidade e parâmetros sanguíneos de cordeiros submetidos a dietas com torta de dendê oriunda da produção de biodiesel. Arch Zootecn 2011; 60:903-912.

11. Correia $B R$, Oliveira RL, Jaeger SMPL, Bagaldo AR, Carvalho GGP, Oliveira GJC, Lima FHS, Oliveira PA. Consumo, digestibilidade e $\mathrm{pH}$ ruminal de novilhos submetidos a dietas com tortas oriundas da produção do biodiesel em substituição ao farelo de soja. Arq Bras Med Vet Zootecn $2011 ; 63: 356-363$.

12. Ribeiro RDX, Oliveira RL, Macome $F M$, Bagaldo AR, Silva MCA, Ribeiro CVDM, Carvalho GGP, Lanna DPD. Meat Quality of Lambs Fed on Palm Kernel Meal, a Byproduct of Biodiesel Production. Asian Australas J Anim Sci 2011; 24:1399-1406.

13. Agy MSFA, Oliveira RL, Ribeiro CVDM, Bagaldo AR, Araúlo GGL, Pinto LFB, Ribeiro RDX. Sunflower cake from biodiesel production fed to crossbred Boer kids. R Bras Zootec 2012; 41:123-130.

14. Santos EM, Zanine AM, Dantas PA, Dórea JRR, Silva TC, Pereira OG, Lana RP, Costa RG. Composição bromatológica, perdas e perfil fermentativo de silagens de capimelefante com níveis de inclusão de jaca. $R$ Bras Saúde Prod An 2008; 9:64-73.

15. Suarez $P A Z$, Santos ALF, Rodrigues JP, Alves MB. Biocombustíveis a partir de óleos e gorduras: desafios tecnológicos para viabilizá-los. Quim Nova 2009; 32:768-775.

16. Silva DJ, Queiroz AC. Análise de alimentos: métodos químicos e biológicos. 3.ed. Viçosa, MG: Editora UFV; 2002.

17. PLAYNE, MJ; MCDONALD, P. The buffering constituints of herbage and silage. J Sci Food Agric 1966; 17:262-268.

18. Teixeira JC, Andrade GA. Carboidratos na alimentação de ruminantes. Lavras: Simpósio de forragicultura e pastagens/ UFLA; 2001. 2. 
19. Ribeiro RDX, Oliveira RL, Bagaldo $A R$, Faria EFS, Garcez Neto AF, Silva TM, Borja MS, Cardoso Neto BM. Capim-tanzânia ensilado com níveis de farelo de trigo. Rev Bras Saúde Prod An 2008; 9:631-640.

20. Zanine AM, Santos ED, Ferreira DJ, Pereira OG, Carvalho JC. Efeito do farelo de trigo sobre as perdas, recuperação da matéria seca e composição bromatológica da silagem de capim-mombaça. R Bras Zootec 2006; 53:803-809.

21. Oliveira $R L$, Bagaldo $A R$, Ladeira $M M$, Barbosa MAAF, Oliveira RL, Jaeger SMPL. Fontes de lipídeos na dieta de búfalas lactantes: consumo, digestibilidade e N-uréico plasmático. R Bras Zootec 2009; 38:553-559.

22. Fontaneli RS, Durr JW, Basso SMS, Appelt JV, Hauber FA. Avaliação da qualidade de silagens de milho através da espectrometria de reflectância no infravermelho proximal (NIRS). Viçosa: Reunião anual da sociedade brasileira de zootecnia/SBZ; 2000.

23. Costa RS, Gonçalves LC, Rodrigues JAS, Borges I, Rodriguez NM, Bprges ALCC, Gomes RTS. Composição química da planta verde e das silagens de doze cultivares de milho. Viçosa: Reunião anula da sociedade brasileira de zootecnia/SBZ; 2000.

24. Nutrient requirements of dairy cattle. Washington: National Research Council; 2001.
25. Mullingan FJ, Quirke J, Rath M, Caffrey PJ, O'Mara FP. Intake, digestibility, milk production and kinetics of digestion and passage for diets based on maize or grass silage fed to late lactation dairy cows. Livest Prod Sci 2002; 74:113-124.

26. Mello LO DF, Franzolin R, Fernandes LB, Franco VM, Alves TC. Avaliação do resíduo de nabo forrageiro extraído da produção de biodiesel como suplemento para bovinos de corte em pastagens. Rev Bras Saúde Prod An 2008.9:45-56.

27. Ferrari EJ, Lavezzo W. Qualidade da silagem de capim-elefante (Pennisetum purpureum Schum.) emurchecido ou acrescido de farelo de mandioca. R Bras Zootec 2001; $30: 1424-1431$.

28. Zanine AM, Santos EM, Ferreira DJ, Almeida JCC, Pereira OG. Avaliação das perdas, recuperação da matéria seca e composição bromatológica da silagem de capim-tanzânia com cana-de-açúcar. Rev Uni Rural 2007; 27:40-47.

29. Ferreira $A C H$, Neiva JNM, Rodriguez NM, Campos WE, Borges I. Avaliação nutricional do subproduto da agroindústria de abacaxi como aditivo de silagem de capim-elefante. R Bras Zootec, 2009; 38:223-229. 